\title{
Ascorbic acid activity in adrenal glands of rats with hypervitaminosis $\mathbf{A}$
}

\author{
BY A. K. RAY,* N. R. RAY* AND D. P. SADHU† \\ Department of Physiology and Nutrition, Bengal Veterinary College, \\ Calcutta, India
}

(Received 9 September 1964-Accepted 8 March 1965)

\begin{abstract}
Toxic effects of administering large doses of vitamin A have been known for a long time to occur in human beings as well as in laboratory animals (Josephs, I944; Knudson \& Rothman, I953). Polar bear liver is an unusually potent source of vitamin $A$ and is toxic as a food even for Eskimo's dogs (Rodahl \& Moore, I943). In hypervitaminosis A basal metabolism is lowered (Sadhu \& Brody, 1947) and liver metabolic activity is depressed (Ray \& Sadhu, 1959a, $b$ ). Excess intake of vitamin A causes an increased urinary excretion of ascorbic acid, so that the vitamin $\mathrm{C}$ reserve of the body can become exhausted and vitamin $\mathrm{C}$ deficiency can occur (André \& Gauzin, I954). The investigation described here was planned as a study of the general activities of the body in hypervitaminosis $\mathrm{A}$ in relation to body-weight and the weights of different tissues and also to the oxidation of ascorbic acid in the adrenal gland.
\end{abstract}

\section{EXPERIMENTAL}

\section{Animals and diets}

Forty albino rats weighing between 44 and $49 \mathrm{~g}$ were used from the laboratory stock. They were given the basal diet in the form of a thick paste (Sinha \& Ray, I964, unpublished). The diet was:

$5 \circ \mathrm{g}$

Fried gram (Cicer arietinum L.) powder without husk $\quad 5 \circ \mathrm{g}$

Whole milk I65 g

The composition (parts) was:

$\begin{array}{lrll}\text { Carbohydrate } & 27.7 \mathrm{I} & \text { Calcium } & 0.09 \\ \text { Fat } & 3.54 & \text { Phosphorus } & 0.17 \\ \text { Protein } & 8.58 & \text { Iron } & 0.003 \mathbf{I}\end{array}$

The calorific value was $177.26 \mathrm{kcal} / 100 \mathrm{~g}$.

One group of twenty rats $(T)$ was given orally for to days vitamin $\mathrm{A}$ in the form of Arovit (generously supplied by Hoffman-La Roche Inc. and their agents, Voltas Ltd,

* Present address: Department of Physiology, Bihar Veterinary College, Patna, India.

$\uparrow$ Present address: P. G. College of Animal Science, Indian Veterinary Research Institute, Izatnagar, UP, India. 
India) at the rate of 30000 i.u./rat daily. The other group of twenty rats $(C)$ was pair-fed with group $T$ but had no vitamin A supplement. All the rats had drinking water ad lib.

\section{Sampling of tissues}

Animals were killed on the Ioth day of experiment; their different tissues were immediately removed and weighed quickly after removal of all adhering fatty and connective tissue.

\section{Study of ascorbic acid oxidation}

The oxidation of ascorbic acid effected by the adrenal glands was measured in a Warburg manometer at $38^{\circ}$ with sodium ascorbate as substrate, as described by Umbreit, Burris \& Stauffer (1957). The homogenate was prepared with $1 / 15 \mathrm{M}-$ phosphate buffer at $\mathrm{pH}_{7} \cdot 4$ with a dilution ratio $\mathrm{I}: 80(\mathrm{w} / \mathrm{v})$. Control experiments were also performed without substrate. The control experiment showed negligible activity, and hence is not recorded in detail. The vessel contained $0.5 \mathrm{ml}$ homogenate, $0.5 \mathrm{ml}$ cytochrome $c$ solution $\left(\mathrm{r} \cdot 6 \times 10^{-5} \mathrm{M}\right), 0.2 \mathrm{ml}$ of $20 \%(\mathrm{w} / \mathrm{v}) \mathrm{KOH}$ solution in the centre cup, $0.3 \mathrm{ml}$ sodium ascorbate $(0.1 \times 4 \mathrm{M})$ in the side-arm and sufficient I/ 5 M-phosphate buffer at $\mathrm{pH} 7 \cdot 4$ to make a final volume of $3 \mathrm{ml}$. The gas phase was air, and the ascorbate solution was tipped into the main compartment from the side-arm after $10 \mathrm{~min}$ of temperature equilibration.

\section{RESULTS AND DISCUSSION}

After administration of excess vitamin $A$, the amount of food eaten remained normal for the first 2 or 3 days. After that time the intake was less and became almost negligible within a period of from 8 to Io days. Body-weights also decreased gradually. It was found that after a single toxic dose of 30000 i.u. vitamin A, drowsiness and muscular weakness appeared within $24 \mathrm{~h}$ in young rats. Body activity in general also decreased. When the daily toxic dose of vitamin A was continued, the animals showed typical signs of hypervitaminosis $A$ within 6-8 days. The signs included loss of appetite, loss of body-weight, muscular weakness, loss of hair, appearance of crust around the eyes, sometimes internal haemorrhage, and at a late stage paralysis. Death occurred within $12-15$ days. In an unpublished preliminary experiment it was found that, if vitamin $A$ administration was stopped after the first toxic dose, the rats returned quickly to normal. When administration of excess vitamin $A$ was stopped after Io days, the rats recovered from hypervitaminosis $A$ in about another 2-3 weeks.

It is evident from Table I that, expressed as a percentage of body-weight, the weights of heart, liver, kidney and adrenal glands were greater in the experimental group $(T)$, whereas the weights of brain and spleen did not differ significantly. Excretion of 17 -ketosteroids is increased in hypervitaminosis A (Ray \& Sadhu, 1957). The results are, however, complicated owing to effects of inanition and stress acting simultaneously, though the effect of inanition was counterbalanced to some extent by pair feeding. The action of stress in these rats is also proved by the increased weight of adrenal glands. The increased relative weights of heart, liver, kidney and adrenal glands could have been due to shift of fluid from the circulation to the tissue space as 
Table 1. Mean organ weights, expressed as percentage of body-weights, of twenty rats suffering from hypervitaminosis $A$ (group T) compared with pair-fed control rats (group $C$ )

$\begin{array}{lcccr}\quad \text { Group } C & \text { Group } T & \begin{array}{c}\text { with its } \\ \text { standard error }\end{array} & t \text { value } \\ \text { Heart } & & 0.653 & 0.155 \pm 0.0028 & 55.71^{*} \\ \text { Liver } & 0.498 & 6.058 & 1.039 \pm 0.00331 & 313.29 * \\ \text { Kidney } & 5.019 & 1.453 & 0.414 \pm 0.0051 & 80.92^{*} \\ \text { Adrenal glands† } & 0.039 & 0.0744 & 0.0348 \pm 0.00026 & 133.69^{*} \\ & (18.61 \mathrm{mg}) & (31.25 \mathrm{mg}) & 12.64 \pm 0.636 \mathrm{mg} & 65.38^{*} \\ \text { Brain } & 2.798 & 2.791 & 0.007 \pm 0.0023 & 2.21 \\ \text { Spleen } & 0.821 & 0.809 & 0.012 \pm 0.00175 & 3.42\end{array}$

* Significant at the I \% level.

$\uparrow$ Values in parentheses are the absolute weights.

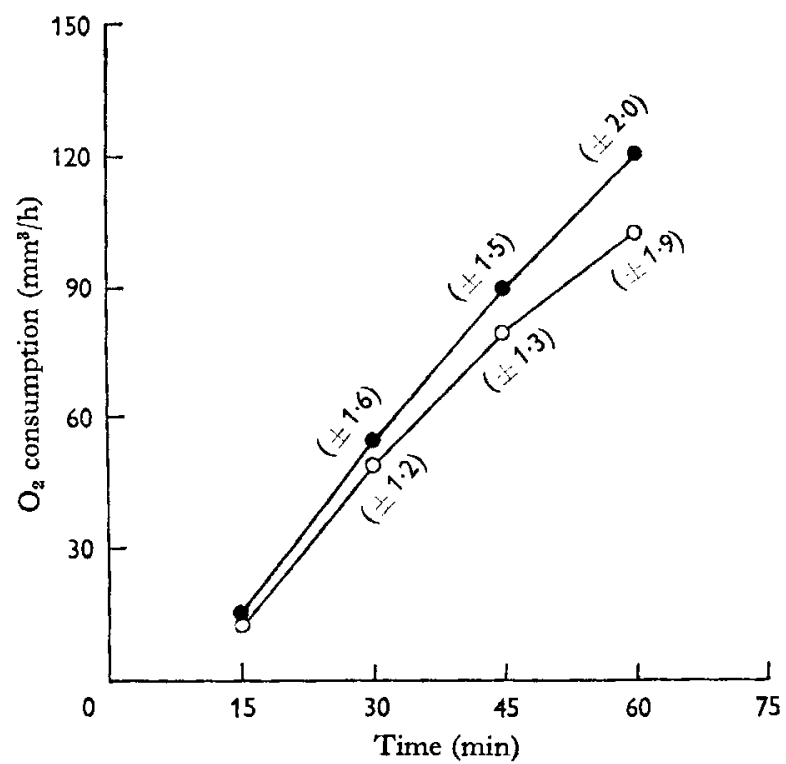

Fig. I. Ascorbic acid activity in the adrenal glands of control rats (group $C$ ) and rats given excess vitamin A (group $T$ ), expressed as the rate of oxygen consumption, with sodium ascorbate (O.II $4 \mathrm{M})$ as substrate, against time course of reaction in min. Each point is the mean value from twelve experiments with its SE. $\bigcirc-0$, group $C ; \bullet-\bullet$, group $T$.

a result of stress (Megel, Wozniak, Sun, Frazier \& Mason, 1962). The absolute weights of the adrenal glands are also shown in Table $\mathbf{r}$.

The ascorbic acid content of the adrenal glands is diminished by stress (Goswami, Trivedi \& Gupta, 196I). Our work (see Fig. I) showed $18 \%$ more ascorbic acid oxidation, expressed as percentage stimulation of oxygen consumption in $\mathrm{mm}^{3}$ during the time course of reaction for a period of $\mathrm{I} h$, in group $T$ than in group $C$.

The bleeding tendency in hypervitaminosis $A$ could have been due to hyperheparinaemia (unpublished). The molecules of both heparin and ascorbic acid oxidase contain the sulphydryl group along with glucosamine (Jorpes, I935; Stark \& Dawson, 
1962). Vitamin A modifies the formation of mucopolysaccharides by affecting the activities of sulphate (Wolf, Varandani \& Johnson, 196r). Vitamin A may contribute to the increased synthesis of heparin and ascorbate oxidase in the system, although further investigation is needed on this point. Ascorbate oxidase present in the adrenal cortex catalyses ascorbic acid oxidation (Harrow, 1950); hence it might be the cause of the reduction in ascorbic acid.

\section{S UMMARY}

I. A single oral dose of 30000 i.u. vitamin A given to albino rats weighing about 44-49 $\mathrm{g}$ produced drowsiness and muscular weakness within $24 \mathrm{~h}$.

2. Similar doses of vitamin A given daily for Io days to twenty rats resulted in gradual loss of appetite and loss of body-weight in comparison with pair-fed control rats.

3. The weights of the hearts, livers, kidneys and adrenal glands of the treated rats, expressed as percentages of their final body-weights, were greater than for the controls.

4. Oxidation of ascorbic acid in the adrenal glands was increased by $18 \%$ in the hypervitaminotic rats compared with the controls. Possible explanations are discussed.

The authors express their gratitude to Dr M. S. Das, Principal, Bengal Veterinary College, Calcutta, India, for his interest and helpful suggestions.

\section{REFERENCES}

André, L. M. \& Gauzin, M. (1954). Bull. Acad. nat. Méd. Ir, 357.

Goswami, S. L., Trivedi, C. P. \& Gupta, R. K. (r96r). Arch. int. Pharmacodyn. 134, I.

Harrow, B. (1950). Textbook of Biochemistry, 5th ed., p. 175. Philadelphia, Pa: W. B. Saunders Co. Jorpes, E. (1935). Naturwissenschaften, 23, I 96.

Josephs, H. W. (1944). Amer. F. Dis. Child. 67, 33 .

Knudson, A. G. \& Rothman, P. E. (1953). Amer. F. Dis. Child. 85, 316.

Megel, H., Wozniak, H., Sun, L., Frazier, E. \& Mason, H. C. (1962). 7. appl. Physiol. 17, 759.

Ray, A. \& Sadhu, D. P. (1957). Indian F. Physiol. 11, I.

Ray, A. \& Sadhu, D. P. (I959a). Amer. F. Physiol. 196, 1274.

Ray, A. \& Sadhu, D. P. (1959b). Nature, Lond., 184, 1323.

Rodahl, K. \& Moore, T. (1943). Biochem. F. 37, 166.

Sadhu, D. P. \& Brody, S. (1947). Amer. F. Physiol. 149, 400.

Stark, G. R. \& Dawson, C. R. (Ig62). F. biol. Chem. 237, 712.

Umbreit, W. W., Burris, R. H. \& Stauffer, J. F. (1957). Manometric Techniques, 3rd ed., p. 175. Minneapolis, Minn.: Burgess Publishing Co.

Wolf, G., Varandani, P. 'T. \& Johnson, B. C. (1961). Biochim. biophys. Acta, 46, 59. 